\title{
ПРОТИВООПУХОЛЕВЫЕ ПРЕПАРАТЫ КОМБИНИРОВАННОГО ДЕЙСТВИЯ ДЛЯ ФОТОДИНАМИЧЕСКОЙ И ХИМИОТЕРАПИИ В ОНКОЛОГИИ НА ОСНОВЕ ПРИРОДНЫХ ХЛОРИНОВ
}

\author{
П.В. Островерхов, Н.С. Кирин, М.А. Грин
}

МИРЭА - Российский технологический университет, Институт тонких химических технологий им. М.В.Ломоносова, 119571, Россия, Москва, пр-кт Вернадского, 86

DOI: 10.19163/MedChemRussia2021-2021-381

E-mail:ostroverhov@mirea.ru

На сегодняшний день существует множество видов онкологических заболеваний, в отношении которых традиционные методы лечения мало эффективны. Примером таких новообразований являются опухоли, обладающие множественной лекарственной устойчивостью (МЛУ). Хирургическое удаление или лучевая терапия не может гарантировать излечение больного из-за возможного продолженного роста опухоли и метастазирования. Применение комбинированных методов является решением данной проблемы, так как использует преимущества нескольких видов воздействия на опухоль. Например, применение сочетанной фотодинамической терапии с химиотерапией показывает высокую эффективность в отношении опухолей, обладающих МЛУ или повышенным сопротивлением окислительному стрессу.

В настоящей работе получены мультифункциональные таргетные комплексы на основе природных хлоринов и химиотерапевтических агентов для реализации сочетанной химио- и ФД- терапии. Присутствие в составе конъюгата фотоактивной хлориновой субъединицы, генерирующей при облучении синглетный кислород, и цитотоксического агента, нацеленно воздействующего на ДНК опухолевых клеток, обуславливает аддитивный противоопухолевый эффект на клеточном и организменном уровне.

Полученные системы могут стать перспективными противоопухолевыми препаратами, разработка которых позволит решить одну из основных проблем химиотерапии - снижение токсического действия на организм за счет повышения селективности накопления в опухоли.

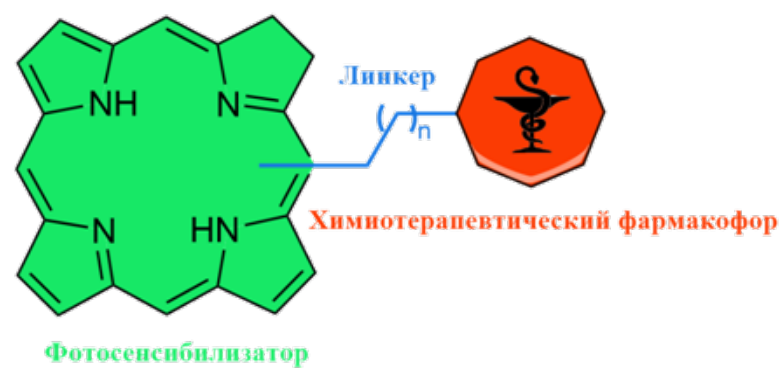

Работа выполнена при поддержке гранта РФФИ № 19-33-90262 Aспиранты.

$$
-381-
$$

